\title{
Investigating the Consequences of elF4E2 (4EHP) Interaction with 4E-Transporter on Its Cellular Distribution in HeLa Cells
}

\author{
Dorota Kubacka ${ }^{1,2}$, Anastasiia Kamenska1, Helen Broomhead', Nicola Minshall', Edward Darzynkiewicz², \\ Nancy Standart ${ }^{1 *}$
}

1 Department of Biochemistry, University of Cambridge, Cambridge, United Kingdom, 2 Division of Biophysics, Institute of Experimental Physics, Faculty of Physics, University of Warsaw, Warsaw, Poland

\begin{abstract}
In addition to the canonical elF4E cap-binding protein, eukaryotes have evolved sequence-related variants with distinct features, some of which have been shown to negatively regulate translation of particular mRNAs, but which remain poorly characterised. Mammalian elF4E proteins have been divided into three classes, with class I representing the canonical cap-binding protein elF4E1. elF4E1 binds elF4G to initiate translation, and other elF4Ebinding proteins such as 4E-BPs and 4E-T prevent this interaction by binding elF4E1 with the same consensus sequence $\mathrm{YX}_{4} \mathrm{~L} \phi$. We investigate here the interaction of human elF4E2 (4EHP), a class II elF4E protein, which binds the cap weakly, with elF4E-transporter protein, 4E-T. We first show that ratios of elF4E1:4E-T range from $50: 1$ to 15:1 in HeLa and HEK293 cells respectively, while those of elF4E2:4E-T vary from 6:1 to 3:1. We next provide evidence that elF4E2 binds 4E-T in the yeast two hybrid assay, as well as in pull-down assays and by recruitment to P-bodies in mammalian cells. We also show that while both elF4E1 and elF4E2 bind 4E-T via the canonical $Y X{ }_{4} \mathrm{~L} \phi$ sequence, nearby downstream sequences also influence elF4E:4E-T interactions. Indirect immunofluorescence was used to demonstrate that elF4E2, normally homogeneously localised in the cytoplasm, does not redistribute to stress granules in arsenite-treated cells, nor to P-bodies in Actinomycin D-treated cells, in contrast to elF4E1. Moreover, elF4E2 shuttles through nuclei in a Crm1-dependent manner, but in an 4E-T-independent manner, also unlike elF4E1. Altogether we conclude that while both cap-binding proteins interact with 4E-T, and can be recruited by $4 \mathrm{E}-\mathrm{T}$ to P-bodies, elF4E2 functions are likely to be distinct from those of elF4E1, both in the cytoplasm and nucleus, further extending our understanding of mammalian class I and II cap-binding proteins.
\end{abstract}

Citation: Kubacka D, Kamenska A, Broomhead H, Minshall N, Darzynkiewicz E, et al. (2013) Investigating the Consequences of elF4E2 (4EHP) Interaction with 4E-Transporter on Its Cellular Distribution in HeLa Cells. PLoS ONE 8(8): e72761. doi:10.1371/journal.pone.0072761

Editor: Thomas Preiss, The John Curtin School of Medical Research, Australia

Received April 19, 2013; Accepted July 15, 2013; Published August 21, 2013

Copyright: $\odot 2013$ Kubacka et al. This is an open-access article distributed under the terms of the Creative Commons Attribution License, which permits unrestricted use, distribution, and reproduction in any medium, provided the original author and source are credited.

Funding: The work was funded by a project grant from the Wellcome Trust to NS and ED (084885/Z/08/Z). AK gratefully acknowledges the Gates Cambridge Scholarship. The funders had no role in study design, data collection and analysis, decision to publish, or preparation of the manuscript.

Competing interests: The authors have declared that no competing interests exist.

*E-mail: nms@mole.bio.cam.ac.uk

\section{Introduction}

Control of translation in eukaryotes is critical for proper development, cell growth and proliferation, and the most highly regulated level is at initiation. A key player in translation initiation is elF4E, the mRNA 5' cap-binding protein, whose aberrant expression and phosphorylation promotes tumorigenesis and which has also been implicated in mechanisms underlying senescence and autism [1-4]. Translation initiation begins with the rate-limiting binding of the elF4F (elF4E, elF4G and the RNA helicase elF4A) complex to the $5^{\prime}$ cap and is completed upon start codon recognition by the pre-initiation complex. elF4E recruits ribosomes to mRNA 5' ends through specific binding to elF4G, which also contains binding sites for elF3, associated with the small ribosomal subunit. elF4E sandwiches the $m^{7} G$ cap via conserved tryptophan residues and binds the consensus $\mathrm{YXXXXL \phi}$ sequence in elF4G (where $\phi$ is hydrophobic and $X$ is any amino acid) on its convex side. Well-characterised inhibitors of translation initiation known as elF4E-binding proteins (4E-BPs) contain similar $\mathrm{YX}{ }_{4} \mathrm{~L} \phi$ motifs. These small proteins have been described as molecular mimics of elF4G, since they act by competing for the same binding site of elF4E. When hypophosphorylated in quiescent cells, 4E-BPs associate with elF4E, preventing elF4E from binding elF4G, and blocking the formation of the translation initiation complex [5-7].

In addition to this well-characterised canonical elF4E capbinding protein, eukaryotes have evolved sequence-related 
variants with distinct features, some of which have been shown to regulate translation of particular mRNAs rather than participate in global translation initiation. For example, Drosophila melanogaster possess eight elF4E proteins, with individual developmental expression profiles, and with varying abilities to bind the cap, elF4G and 4E-BP $[8,9]$. In C. elegans, the five elF4E proteins differ in their recognition of mono and trimethylated caps, and regulate sub-sets of mRNAs [10,11]. Mammalian elF4E proteins have been divided into three classes, with class I representing the canonical cap-binding protein $[12,13]$.

Our study focuses on human elF4E2, a 245 amino acid long ubiquitously expressed protein, also known as 4EHP (elF4E homologous protein) or elF4EL3 (elF4E-like 3), a class II protein, which is $30 \%$ identical and $60 \%$ similar in sequence to elF4E1 $[13,14]$. elF4E2 does not interact with elF4G and binds $4 \mathrm{E}-\mathrm{BPs}$ relatively weakly $[12,14,15]$. Its affinity for the cap is approx $30-100 \times$ lower than that of elF4E1, largely due to an extension of one loop which creates the ligand binding site and thus negatively affects formation of the three stacked aromatic rings, Trp $124 / \mathrm{m}^{7} \mathrm{Gua} / \mathrm{Ty} \mathrm{r} 78$, and also different arrangements of basic amino acids interacting with the phosphate chain $[15,16]$. Hence elF4E2, on its own, will not compete with elF4E1 for mRNA effectively, but may do so with a partner protein. Indeed its Drosophila homologue, d4EHP (elF4E-8) binds Bicoid, an RNA-binding protein which recognises a 3' UTR element in caudal mRNA to specifically repress its translation [17] and, similarly, mouse 4EHP binds cytoplasmic Prep1 inhibiting Hoxb4 translation [18]. Recently, Morita et al. showed that elF4E2, which forms a translational repressor complex with GIGYF2 (Grb10-interacting GYF protein 2) and zinc finger protein 598, is essential for mammalian development, since elF4E2 ko mice are not viable, with the embryos dying perinatally [19].

We investigate here the interaction of elF4E2 with 4E$\mathrm{T}$ (ransporter), an elF4E-binding protein. Mammalian 4E-T was first characterized as a large protein which binds elF4E via $Y X$ ${ }_{4} \mathrm{~L} \phi$ and prevents elF4E interacting with elF4G [20]. Indeed, $4 \mathrm{E}-\mathrm{T}$ was shown to inhibit cap-dependent translation as well as to regulate ARE-(AU-rich) mRNA stability [20]. 4E-T is a component of $\mathrm{P}$-(rocessing) bodies and a nucleocytoplasmic protein which transports elF4E into nuclei [21-23]. P-bodies, distinct cytoplasmic foci, contain mRNA, microRNAs, mRNA decay enzymes, and RNA-binding proteins/translational repressors but not ribosomes, and are understood to participate in mRNA decay and in reversible translational repression including that mediated by microRNAs. In addition to decapping, deadenylase and exonuclease activities, components include elF4E, the only translation initiation resident in P-bodies, p54/rck RNA helicase, Pat1b, Lsm14A, as well as 4E-T [24-26].

Control of translation is of pivotal importance during early development, particularly during meiotic maturation and early embryogenesis, as transcription is shut down. Previously, we showed that $4 \mathrm{E}-\mathrm{T}$ is a major component of CPEB (cytoplasmic polyadenylation element-binding protein) mRNP in Xenopus oocytes [27,28]. CPEB, an RNA-binding protein, regulates 3' UTR CPE-containing mRNAs such as cyclin B mRNA by acting both as a translational repressor in the oocyte and a translational activator in eggs, where it participates in cytoplasmic polyadenylation [29,30]. During the course of Xenopus oogenesis (stage I-VI), the class I elF4E cap-binding proteins are differentially expressed, with the early expressed elF4E1b protein being replaced by the closely related canonical elF4E1 protein. We also showed that CPEB RNP obtained by immunoprecipitation and gel filtration contained Xp54 RNA helicase, Pat1a, Lsm14B, 4E-T and elF4E1b as the most abundant protein partners of $C P E B$, resembling thus $P$ bodies. All these factors are expressed in early stages of oogenesis, and form a very stable complex [27]. While the detailed function of elF4E1b in CPEB RNP remains to be established, it is interesting to note that this protein variant, which binds $m^{7}$ GTP-Sepharose inefficiently [27], is evolutionarily conserved, arising in Tetrapoda as a result of the ancestral eIF4E locus duplication. Moreover, EST evidence suggests its oocyte-restricted expression is also conserved [31]. We proposed a repressed closed loop model whereby CPEB bound to regulated mRNA via their 3' UTR CPE elements interact directly or indirectly with $4 \mathrm{E}-\mathrm{T}$ which binds elF4E1b, precluding elF4G recognition of the cap structure, and thereby inhibiting translation [27,32]. Drosophila Cup, partially related in sequence to vertebrate $4 \mathrm{E}-\mathrm{T}$, has similarly been proposed to inhibit oskar and nanos mRNAs by interacting with the 3' UTR-binding proteins Bruno and Smaug respectively, as well as elF4E [33,34].

In view of our interest in cap-binding proteins interactions with 4E-T, we first assessed their expression in HeLa and HEK293 cells, and show that elF4E:4E-T ratios range from 3:1 to $50: 1$, depending on the cell line and the cap-binding protein. We demonstrate using several lines of evidence that elF4E2 binds 4E-T, and that while both elF4E2 and elF4E1 bind 4E-T via the $\mathrm{YX}{ }_{4} \mathrm{~L} \phi$ motif, nearby downstream sequences also influence elF4E1/2:4E-T interactions. elF4E2, normally homogeneously localised in the cytoplasm, as is elF4E1, however does not redistribute to stress granules in arsenitetreated cells, nor to P-bodies in Actinomycin D-treated cells, in contrast to elF4E1. Furthermore, elF4E2 shuttles through nuclei in a Crm1-dependent manner, but in an 4E-Tindependent manner, also unlike elF4E1. Altogether we conclude that while both cap-binding proteins interact with $4 \mathrm{E}$ $\mathrm{T}$, and can be recruited by $4 \mathrm{E}-\mathrm{T}$ to $\mathrm{P}$-bodies, elF4E2 nuclear and cytoplasmic functions are likely to be distinct from those of elF4E1.

\section{Materials and Methods}

\section{Plasmids and protein expression in E. coli}

Human elF4E2 cDNA, amplified from pcDNA3-HA-elF4E2 vector (gift from Nahum Sonenberg) by PCR was subcloned into pEGFP-C1 (EcoRI/Xmal restriction sites) and yeast vectors, pGADT7 and pGBKT7 (BD Biosciences-Clontech), using Ndel/BamHI sites. Similarly, human 4E-T cDNA in the pEYFP-C1 vector (gift from Rheinhard Luhrmann [22]) was subcloned into pEGFP-C1 (Kpnl/Xmal) and yeast vectors (Ndel/BamHI). elF4E2 cDNA C-terminally truncated by $69 \mathrm{bp}$ was amplified by PCR and recloned into pcDNA3-HA vector 
(BamHI/Xhol). FLAG-MS2-4E-T was constructed by inserting 3XFLAG epitope DNA into the Ncol site of the MS2-4E-T plasmid [27] using Pfu DNA polymerase (Stratagene), and similarly for the control FLAG-MS2 control construct. Mutagenesis of 4E-T was carried out in a two step process. For the human protein, $\mathrm{Y} 30 \mathrm{~A}$ and $\mathrm{Y} 55 \mathrm{~A}$ were mutated first, followed by LL35/36 AA and VW60/61 AA respectively, and similarly in the case of Xenopus 4E-T (Y28,Y53, LL33/34 AA, VW58/59 AA respectively). All cloning and mutagenesis, with the indicated oligonucleotides (Table S1), was carried out using Stratagene QuikChange site-directed mutagenesis kit and verified by sequencing.

Recombinant His-4E-T was prepared by the Novagen autoinduction system and denaturing purification on NTAagarose in $8 \mathrm{M}$ urea and elution with $\mathrm{pH} 4.5$ buffer, according to Qiagen. Recombinant elF4E1 and elF4E2 proteins were expressed as inclusion bodies in Rosetta2 (DE3), then purified under denaturing conditions (4-6 M guanidinium hydrochloride) and refolded by one step dialysis as described in [16]. Additional purification by anion-exchange chromatography gave homogenous fractions of proteins.

\section{Protein quantitation}

Quantitative analysis of endogenous elF4E1, elF4E2 and 4E-T was performed by comparison of a concentration series of protein lysates obtained from HeLa and HEK293 cells with known amounts of purified recombinant protein counterparts loaded on the same gel. Cultures of HeLa and HEK293 cells were prepared in the same size 6-well plates and incubated in parallel. Cells from both cultures were counted using a hemocytometer, and lysates were prepared in RIPA buffer, whose protein concentration was determined by the Bradford assay. Western blots with a concentration series of recombinant elF4E1, elF4E2 and 4E-T proteins, quantitated with known amounts of BSA, alongside lysates from HeLa and HEK293 cells, were developed with ECL.

\section{Y2H double transformations and selection}

A yeast two-hybrid assay was performed using the GAL4based two-hybrid system adopted from Clontech. pGBK-protein constructs were transformed into $\mathrm{AH} 109$ cells on selective medium (minimal SD base supplemented with $2 \%$ glucose and the required dropout solution, -Trp in this case). Singly transformed strains were used as a yeast stock in which to transform the pGAD-protein constructs. Double transformed cells were selected on -Leu/-Trp dropout medium suitable for pGBKT7 and pGADT7 vectors containing TRP1 and LEU2 nutritional markers, respectively. pGBKT7 constructs were verified that they did not autonomously activate reporter genes and interaction of proteins was checked on high stringency Ade/-His/-Leu/-Trp dropout medium. Lamin C (pGBKT7-Lamin) and SV40 large T-antigen (pGADT7-T) co-transformants were used as negative controls.

\section{Cell culture, transfection and drug treatments}

HeLa and HEK293 cells were routinely grown in DMEM supplemented with $10 \%$ fetal calf serum. Transient transfections were performed in 24-well plates using $1 \mu \mathrm{l}$ of
Lipofectamine 2000 (Invitrogen) and $0.5 \mu \mathrm{g}$ of plasmid constructs, or in 6-well plates using $3 \mu$ l of Lipofectamine 2000 and $3 \mu \mathrm{g}$ of siRNA. The 4E-T siRNA was 5' CAGUCGAGUGGAGUGUACAUUGUdTdT, purchased from Thermo Scientific, and the control $\beta$-globin siRNA was described in [35]. Cells were fixed and stained with the appropriate antibody $24 \mathrm{hrs}$ after plasmid transfection or $48 \mathrm{hrs}$ after siRNA transfection.

To induce oxidative stress, cells were incubated in media supplemented with $0.5 \mathrm{mM}$ sodium arsenite (Sigma) for $30 \mathrm{~min}$, then allowed to recover for $30 \mathrm{~min}$ in the absence of arsenite. For transcription inhibition of RNA polymerase I and II, $4 \mu \mathrm{M}$ Actinomycin D (ActD) (in ethanol) was used. To inhibit Crm1dependent export, Leptomycin B (LMB) (in methanol) (Sigma) was used at a final concentration of $10 \mathrm{nM}$ for $5 \mathrm{hrs}$. The reported outcomes of these treatments were seen in all cells. Addition of the same volume of methanol or ethanol to the cells was used as a control for these inhibitor experiments. Cells were scraped in phosphate-buffered saline (PBS) and resuspended in RIPA buffer $(50 \mathrm{mM}$ Tris- $\mathrm{HCl} \mathrm{pH} 8,150 \mathrm{mM}$ $\mathrm{NaCl}, 1 \%$ Triton $\mathrm{X}-100,0.5 \% \mathrm{NaDOC}, 0.1 \% \mathrm{SDS}$ ) or NET buffer with non-ionic detergent for immunoprecipitation assays (50 mM Tris- $\mathrm{HCl} \mathrm{pH} 7.5,150 \mathrm{mM} \mathrm{NaCl}, 1 \mathrm{mM}$ EDTA, $0.5 \%$ Nonidet P-40, $0.25 \%$ gelatin) and incubated on ice $20 \mathrm{~min}$. Buffers for lysis were supplemented with Complete Protease Inhibitor cocktail (Roche). Soluble proteins were recovered after centrifugation at $10000 \mathrm{rpm}$ at $4^{\circ} \mathrm{C}$ for $10 \mathrm{~min}$ and quantitated by the Bradford method.

\section{Immunofluorescence}

Cells were plated on $13 \mathrm{~mm}$ glass coverslips in 24-well plates. Cells were fixed in $4 \%$ paraformaldehyde for $20 \mathrm{~min}$, washed three times with phosphate buffered saline (PBS) and permeabilized in PBS with $0.5 \%$ Triton $X-100$ for 4 min $30 \mathrm{sec}$ followed by three PBS washes. Cells were incubated with primary antibodies for $1 \mathrm{hr}$ using chicken elF4EL3/eIF4E2 (1:200; Novus Biologicals), mouse elF4E1 (1:1000; Santa Cruz), goat 4E-T (1:200; Abcam), rabbit Pat1b (1:100), rabbit rck/p54 (1:1000; Bethyl Laboratories), rat HA (1:200; Roche), mouse G3BP (1:200; BD Biosciences), goat TIAR (1:500; Santa Cruz). The cells were then washed three times in PBS, followed by the incubation of the secondary antibodies conjugated to Rhodamine Red-X RRX, Alexa Fluor 488 or Cumarin AMCA fluorescent probes used at a 1:1000 dilution (Jackson ImmunoResearch Laboratories) for $1 \mathrm{hr}$. After rinsing three times with PBS, cells were stained with DAPI $(1.25 \mu \mathrm{g} / \mathrm{ml})$ for $10 \mathrm{sec}$. The coverslips were mounted in Citifluor (Citifluor Labs). All steps were performed at room temperature. Cells were observed under a Zeiss Axioimager M1 fluorescent microscope with a Plan-Apochromat 100/1.4 Oil DIC objective. Where indicated, $>100$ cells from several independent experiments were counted to assess the number of cells with P-bodies containing elF4E2 and 4E-T (or as stated). We did not distinguish between small or large foci, or count the number of P-bodies per cell. 


\section{GFP-Trap pull-down assays}

GFP-Trap $®$ Magnetic beads (Chromotek) (25 $\mu$ l per sample) were re-suspended in $250 \mu \mathrm{l}$ ice-cold NET buffer in hydrophobic tubes. Washed beads were incubated with $1 \mathrm{mg}$ lysate protein, prepared from GFP-4E-T transfected HEK293-T cells, in $1 \mathrm{ml} \mathrm{NET} \mathrm{buffer} \mathrm{supplemented} \mathrm{with} \mathrm{Protease} \mathrm{Inhibitor}$ cocktail, for $1.25 \mathrm{~h}$ at $4^{\circ} \mathrm{C}$ with constant rotation. Supernatants were then removed, beads washed and associated proteins eluted in SDS sample buffer (2\% SDS, $80 \mathrm{mM}$ Tris- $\mathrm{HCl} \mathrm{pH} 6.8$, $10 \%$ glycerol, $5 \%$-mercaptoethanol, $0.0001 \%$ bromophenol blue) prior to gel electrophoresis and western blotting.

\section{Immunoprecipitation of elF4E2}

Chicken IgY Precipitating Resin (GenScript) consisting of agarose beads coupled to Goat Anti-Chicken IgY was used for immunoprecipitation of human elF4E2. First, $10 \mu \mathrm{l}$ of beads were incubated with 0.5 to $2 \mu \mathrm{l}$ of chicken $\alpha$-elF4E2 (no antibody for control) in $1 \mathrm{ml} \mathrm{NET}$ buffer for $2 \mathrm{hrs}$ at $4^{\circ} \mathrm{C}$ with constant rotation. The beads were then washed before incubation with $1 \mathrm{mg}$ of protein lysate prepared from HeLa cells transfected with HA-elF4E2 plasmid in $1 \mathrm{ml} \mathrm{NET}$ buffer supplemented with Protease Inhibitor cocktail, using the same conditions. Following extensive washing of the beads, associated proteins were eluted with $10 \mu \mathrm{l}$ of SDS sample buffer.

\section{Immunoprecipitation of Xenopus 4E-T}

In vitro transcribed mRNAs encoding FLAG-MS2-x4E-T fusion proteins ( $50 \mathrm{nl}$ at $\sim 500 \mathrm{ng} / \mu \mathrm{l}$ ) were injected into stage $\mathrm{VI}$ oocytes, as described previously [27,28], with 150 oocytes injected for each mRNA. Oocytes were incubated for $36 \mathrm{~h}$ at $18^{\circ} \mathrm{C}$ before harvesting. Extracts were made by addition of $1 \mathrm{ml}$ NET buffer and clarification by centrifugation at $10,000 \mathrm{~g}, 2 \mathrm{x}$ $10 \mathrm{~min}, 4^{\circ} \mathrm{C}$. To each extract were added $20 \mu \mathrm{l}$ of Protein-GSepharose beads and $5 \mu \mathrm{l}$ mouse monoclonal $\alpha-F L A G$ (Sigma; $4.2 \mathrm{mg} / \mathrm{ml}$ ) antibody. The mixture was incubated for $4 \mathrm{~h}$ at $4{ }^{\circ} \mathrm{C}$, with constant rotation, and then centrifuged at $800 \mathrm{~g}, 2 \mathrm{~min}, 4$ ${ }^{\circ} \mathrm{C}$, and the supernatant discarded. The beads were washed 3 $x 1 \mathrm{ml} \mathrm{NET}$ buffer, and bound proteins eluted in $40 \mu \mathrm{l}$ of PBS containing $250 \mu \mathrm{g} / \mathrm{ml}$ FLAG peptide. The eluate was concentrated in a micro-spin column (Pierce) and centrifuged at $13,000 \mathrm{rpm}$ for $1 \mathrm{~min}$, before denaturation in SDS-Sample buffer and western blotting.

\section{Protein gel electrophoresis and western blotting}

SDS-PAGE gels and western blotting were performed as described previously $[28,35]$. Typically, $40 \mu \mathrm{g}$ protein per lane was loaded. Primary antibodies and dilutions used were as follows: chicken elF4E2 (1:2000; Novus Biologicals), rabbit elF4E1 (1:15000; gift from Simon Morley), goat 4E-T (1:500; Abcam), mouse GFP (1:2000; Santa Cruz), rabbit p54/rck (Bethyl Labs; 1:2000), mouse CPEB [36] and rabbit MS2 antibodies [62]. Western blots were subsequently detected by enhanced chemiluminescence (ECL). Magic Mark XP Standard Western proteins (Invitrogen) were used as molecular weight markers.

\section{Results and Discussion}

\section{Expression and quantitation of elF4E1, elF4E2 and 4E-T in HeLa and HEK293 cells}

To examine the expression of elF4E2, we first identified an elF4E2-specific antibody. Indeed, we found several commercial antibodies failing to detect this protein, with the exception of the chicken anti-elF4EL3 antibody, which, as Figure 1A shows, detects both GFP-eIF4E2, HA-elF4E2 and an endogenous protein of the predicted size of $28 \mathrm{kDa}$ in HeLa cells. We compared the expression of elF4E1, elF4E2 and 4E-T in HeLa and HEK293 cells, probably the two most commonly used mammalian cell lines (Figure 1B and 1C). Levels of elF4E1 and elF4E2 are similar in both cell lines, with HeLa cells possessing slightly higher levels of elF4E1 than HEK293 cells, though 4E$T$ was significantly more expressed in HEK293 than in HeLa cells. We also noted that in HEK293 cells 4E-T migrates solely as the lower band of the doublet observed in HeLa cells, possibly indicating differential phosphorylation in the two cell lines (Figure 1B).

Using a concentration series of recombinant human elF4E1, elF4E2 and 4E-T proteins made in $E$. coli alongside lysates prepared from HeLa and HEK293 cells in western blotting (data not shown), we estimated their levels in terms of protein copies per cell (summarised in Figure 1C). While these levels are higher than those obtained from recent proteome mass spectrometry determinations in U2OS, HeLa and NIH 3T3 cells and there are indeed considerable differences between these proteomic studies themselves [37-39], the following conclusions using all the data can be made. First, elF4E1 levels are consistently higher than those of elF4E2 (with the exception of U2OS cells where they are equal), and second, 4E-T levels are significantly much lower than either elF4E protein. Our quantitation data show that elF4E1:elF4E2 ratios range from approx $8: 1$ to $5: 1$ in HeLa and HEK293 cells respectively, while ratios of elF4E1:4E-T range from $50: 1$ to 15:1, and those of elF4E2:4E-T vary from $6: 1$ to $3: 1$ (Figure 1C). We also considered the levels of elF4G1+3 and $4 \mathrm{E}-$ $\mathrm{BP} 1+2$ in the proteomic studies [37-39], and concluded that $4 \mathrm{E}-\mathrm{T}$ is the least expressed of these elF4E-binding proteins in mammalian cells. Interestingly, too, none of these studies reported significant levels of elF4E3. Altogether, these data indicate that elF4E1 is the principal elF4E protein in mammalian cells, and that elF4E:4E-T ratios can vary from $3: 1$ to $50: 1$ depending on the cell and the cap-binding protein.

\section{elF4E2 binds 4E-T via $\mathrm{YX} \mathrm{H}_{4} \mathrm{LL}$ and a nearby downstream sequence}

elF4E1 binding to $4 \mathrm{E}-\mathrm{T}$ via its $\mathrm{N}$-terminal $\mathrm{YX}{ }_{4} \mathrm{LL}$ sequence has been reported previously, and shown to prevent interaction with elF4G, reducing translation initiation of capped mRNAs $[20,21,23,27]$. Large scale yeast protein-protein interaction screens suggested 4E-T also interacts with elF4E2 [40]. First, we verified that elF4E2 binds $4 \mathrm{E}-\mathrm{T}$ in the yeast two hybrid system. AH109 cells were transformed with pGADT7-4E-T and pGBKT7-4E2 plasmids and grown in -Leu/-Trp dropout medium to select for both plasmids. Stocks made from single colonies of double transformants were re-streaked on both -Leu/-Trp 
A

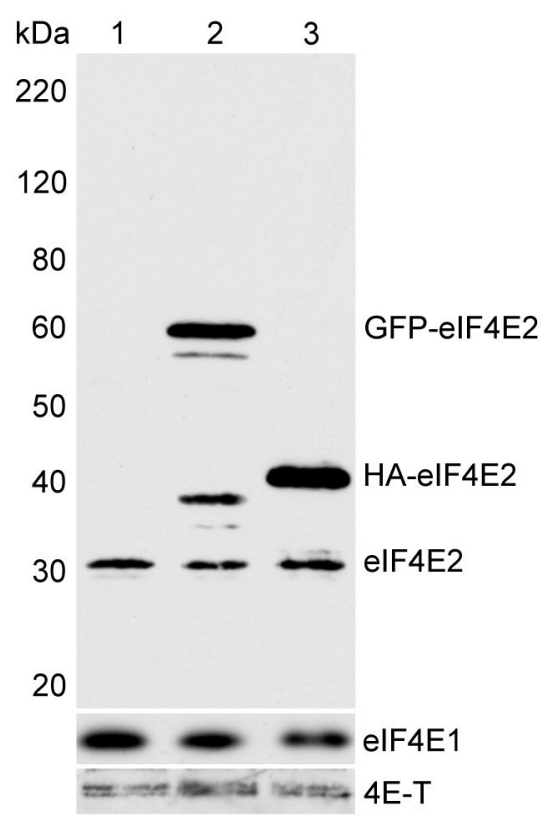

B

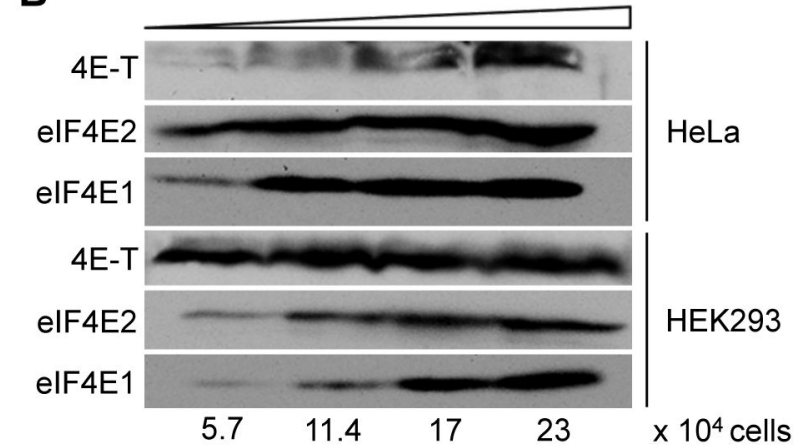

C

\begin{tabular}{|c|c|c|c|}
\hline \multirow{2}{*}{} & elF4E1 & elF4E2 & 4E-T \\
\cline { 2 - 4 } & \multicolumn{3}{|c|}{ Protein copies per cell } \\
\hline HeLa & $2.3 \times 10^{6}$ & $2.8 \times 10^{5}$ & $4.7 \times 10^{4}$ \\
\hline HEK 293 & $1.3 \times 10^{6}$ & $2.8 \times 10^{5}$ & $8.7 \times 10^{4}$ \\
\hline \multicolumn{4}{|c|}{} \\
\hline HeLa $^{36}$ & $6.6 \times 10^{5}$ & $2.3 \times 10^{5}$ & $6.3 \times 10^{3}$ \\
\hline U2OS $^{35}$ & $3.44 \times 10^{4}$ & $3.44 \times 10^{4}$ & $1.34 \times 10^{3}$ \\
\hline NIH3 $^{37}$ & $1.94 \times 10^{5}$ & $1.28 \times 10^{4}$ & nd \\
\hline
\end{tabular}

Figure 1. Quantitation of elF4E1, elF4E2 and 4E-T levels. A. Verification of chicken elF4EL3/elF4E2 antibody using untransfected Hela cells (1), and cells overexpressing GFP-elF4E2 (2) and HA-elF4E2 (3). Top panel developed with elF4E2 antibody, bottom panels with elF4E1 and 4E-T antibodies. Molecular weight standards are indicated in kDa. B. Comparison of elF4E1, elF4E2 and 4E-T levels in HeLa and HEK293 cells analysed by western blotting with indicated antibodies. Increasing amounts of lysate from HeLa cells (20, 40 and $80 \mu$ g total protein) and HEK293 cells (10, 20 and $40 \mu \mathrm{g})$ approximating to 5.7, 11.4, 17 and $23 \times 10^{4}$ cells. C. Table comparing elF4E1, elF4E2 and 4E-T levels (protein copies/per cell) in HeLa and HEK293 determined by western blotting (top), to those reported in genome-wide mass spectrometry studies in HeLa [35], U20S [34] and NIH3T3 [36] cells.

doi: 10.1371/journal.pone.0072761.g001

and -Ade/-His/-Leu/-Trp dropout plates to screen for plasmid retention and high-stringency protein-protein interactions, respectively. Yeast growth in stringent conditions was supported by $4 \mathrm{E}-\mathrm{T}$ co-expressed with elF4E2, with no growth in the case of controls (Figure S1A). The interaction was next assessed in HeLa cells over-expressing GFP-4E-T. In contrast to untransfected cells in which cellular elF4E2 is essentially homogeneously distributed in the cytoplasm, ectopic 4E-T recruits elF4E2 to P-bodies (Figure $2 \mathrm{~A}$ ), as was reported for tagged and cellular elF4E1 ( [20,23], and Figure S2). We found that elF4E2 co-localised with GFP-4E-T in P-bodies in approx. $70 \%$ of cells, relative to untransfected cells where it only colocalised with $4 \mathrm{E}-\mathrm{T}$ P-bodies in $20 \%$ of cells, as verified by immunostaining. We confirmed this redistribution from the cytoplasm to P-bodies with HA-tagged elF4E2, where it colocalises with GFP-4E-T in approx. $75 \%$ of transfected cells (Figure 2A). Moreover, we show that elF4E2 does not localise to P-bodies containing GFP-4E-T with the mutations in the critical tyrosine and leucine residues of the $\mathrm{Y}^{30} \mathrm{X}_{4} \mathrm{LL}$ motif (Figure 2B and Figure S2), indicating that elF4E2 associates with $4 \mathrm{E}-\mathrm{T}$ in a similar manner as elF4E1.
Previously characterised protein partners of elF4E2/4EHP in fly and mammalian cells, including Bicoid [17], Prep1 [18] and GIGYF2 [41], were shown to interact via a slightly extended Nterminal binding sequence of $\mathrm{YX}{ }_{6} \mathrm{~L} \phi$ or $\mathrm{YXYX}{ }_{4} \mathrm{~L} \phi$ (Figure $3 \mathrm{~A}$ ). We thus examined whether $4 \mathrm{E}-\mathrm{T}$ proteins possess this extended sequence. Interestingly, with the exception of several (but not all) fish 4E-T sequences (Danio rerio, Oreochromis niloticus and Oryzias latipes, though not Takifugu rubripes), which contained an additional tyrosine at -2 position relative to the consensus tyrosine, all other vertebrates lacked this upstream residue. Examining the sequence of $4 \mathrm{E}-\mathrm{T}$, we noted a possible nearby downstream elF4E-binding site $\mathrm{Y}^{55} \mathrm{X}_{4} \mathrm{VW}$, that is conserved in vertebrates, including Xenopus (Figure $3 A)$. While this putative additional sequence is not strictly speaking a consensus sequence, we were intrigued by the potential of sequences downstream of the consensus site in enhancing elF4E-binding, noted in both $4 \mathrm{E}-\mathrm{BP}$ and elF4G $[42,43]$.

To assess this possibility, we employed a pull-down assay with lysates from HEK293 cells overexpressing GFP-4E-T using the GFP-Trap [44], as a more sensitive method to detect 
A
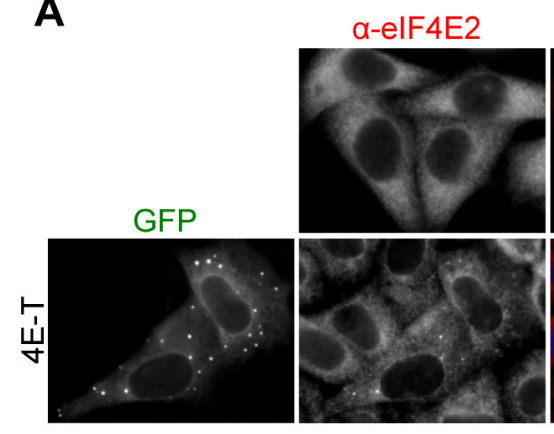

HA-elF4E2
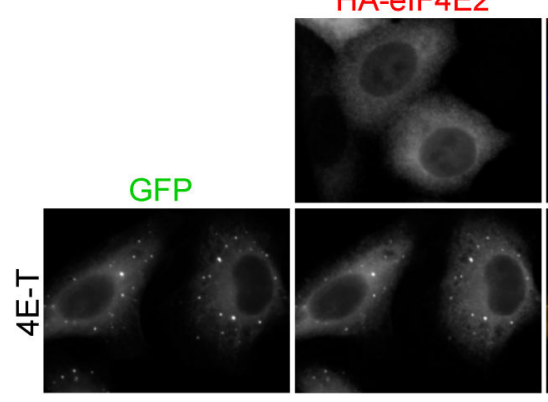

B
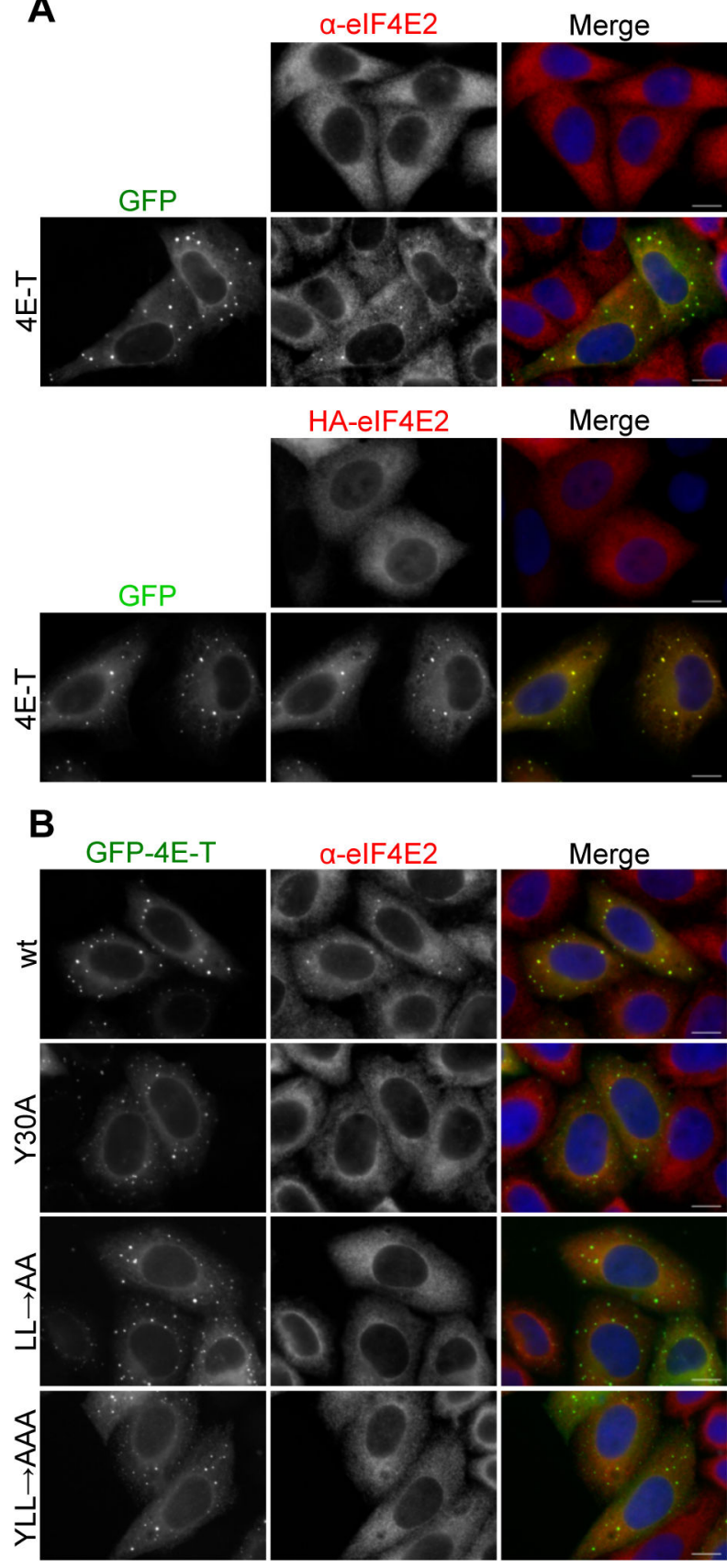

Merge

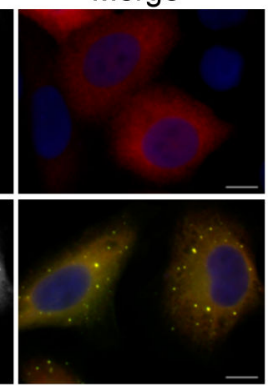

Figure 2. elF4E2 is recruited to P-bodies by ectopic 4ET. A. Cellular elF4E2 distribution in HeLa cells was assessed by indirect immunofluorescence in the absence and presence of GFP-4E-T, and similarly for HA-tagged elF4E2 cotransfected or not with GFP-4E-T. B. Wild-type but not mutant GFP-4E-T recruits elF4E2 to P-bodies. Mutations in the 4E-T elF4E-binding site residues $\mathrm{Y}^{30} \mathrm{X}_{4} \mathrm{LL}$ to alanine are indicated. Cells were also stained with DAPI. Scale bar, $10 \mu \mathrm{m}$. doi: 10.1371/journal.pone.0072761.g002

interactions in mammalian cells than the P-body recruitment approach. First, we confirmed that elF4E2 binds GFP-4E-T, and comparison of input and immunoprecipitated levels indicates that elF4E2 binds with apparent lower affinity to 4E-T than does elF4E1 (Figure 3B, lanes 2 and 9). Furthermore, in a reciprocal immunoprecipitation, HA-elF4E2 brings down endogenous 4E-T (Figure S1B). Therefore in mammalian cells, 4E-T interacts with elF4E2 as well as elF4E1. Moreover, mutation of the critical conserved tyrosine and leucines in $\mathrm{Y}^{30} \mathrm{X}_{4} \mathrm{LL}$ or just the tyrosine on its own to alanine abrogated the interaction between GFP-4E-T and elF4E2, in agreement with the HeLa P-body data (Figure 2B), as well as between elF4E1 and GFP-4E-T (Figure 3B, lanes 10 and 12). We next tested whether the $\mathrm{Y}^{55} \mathrm{X}_{4} \mathrm{VW}$ binding site contributes to elF4E binding. Mutation of $\mathrm{Y}^{55}$ to alanine reduced binding of elF4E1 to $4 \mathrm{E}-\mathrm{T}$, and all interaction was lost with the triple mutation of $\mathrm{Y}^{55} \mathrm{VW}^{6061}$ positions, while no elF4E2 binding was detected with either mutant 4E-T protein (Figure 3B, lanes 11 and 13). In agreement with these pull-down results, the single tyrosine mutation ( $\mathrm{Y}^{55}$ to $\mathrm{A}$ ) in GFP-4E-T expressed in HeLa cells largely unaffected elF4E1 localisation in P-bodies ( $w$ t and $\mathrm{Y}^{55}$ both approx. $90 \%$ of cells with P-bodies) while preventing that of elF4E2 (wt and $\mathrm{Y}^{55}$ approx. 70 and $10 \%$ of cells respectively with P-bodies; Figure S2).

Altogether, our data thus suggests that while both elF4E1 and eIF4E2 interact with sequences downstream of $\mathrm{Y}^{30} \mathrm{X}_{4} \mathrm{LL}$ of $4 \mathrm{E}-\mathrm{T}$, the contribution of the downstream sequence is less important in the case of elF4E1, indicating that despite the participation of the same region of $4 \mathrm{E}-\mathrm{T}$, formation of $4 \mathrm{E}-$ T:elF4E1/2 complexes is differentially stabilised.

\section{In Xenopus oocytes, elF4E1 binding to 4E-T is also sensitive to the same downstream mutations}

We next examined the interaction between 4E-T and elF4E proteins in Xenopus oocytes. FLAG-MS2-tagged $x 4 \mathrm{E}-\mathrm{T}$ and the control FLAG-MS2 protein were expressed from in vitro transcribed mRNA microinjected into stage VI oocytes, and coprecipitation of endogenous elF4E1 proteins by FLAG antibodies was assessed by western blotting. Unlike endogenous 4E-T, ectopic 4E-T can bind both short and long forms of elF4E1 (differing in an 18 amino acid repeat) [27], though it preferentially interacts with elF4E1b, as shown by comparing the input and the wild-type protein bound lanes (Figure 3C, lanes 1 and 3). Mutation of the consensus elF4Ebinding site, $\mathrm{Y}^{28} \mathrm{LL}^{33 / 34}$ to AAA in FLAG-MS2-4E-T abolishes all elF4E1a binding as does mutation of the second putative site $\mathrm{Y}^{53} \mathrm{VW}^{5659}$ to $\mathrm{AAA}$, while both sets of mutations also abolish most, though not all, elF4E1b binding (Figure 3C, lanes 4 and 5). Neither set of mutations abrogates 4E-T coimmunoprecipitating CPEB or Xp54 helicase, demonstrating that they do not result in extensive misfolding. We could not assess Xenopus 4E-T binding to elF4E2, since the chicken elF4EL3 antibody does not detect an oocyte protein of the appropriate size, though we suspect elF4E2 to be maternally expressed, as it is in mice [18].

Altogether we conclude that sequences downstream of the canonical elF4E-binding site in human or Xenopus 4E-T, including the $\mathrm{YX}{ }_{4} \mathrm{VW}$ motif, strongly influence $4 \mathrm{E}-\mathrm{T}$ interaction with elF4E1 or elF4E2 isoforms and may regulate their differential binding. The exact delineation of the additional 
A

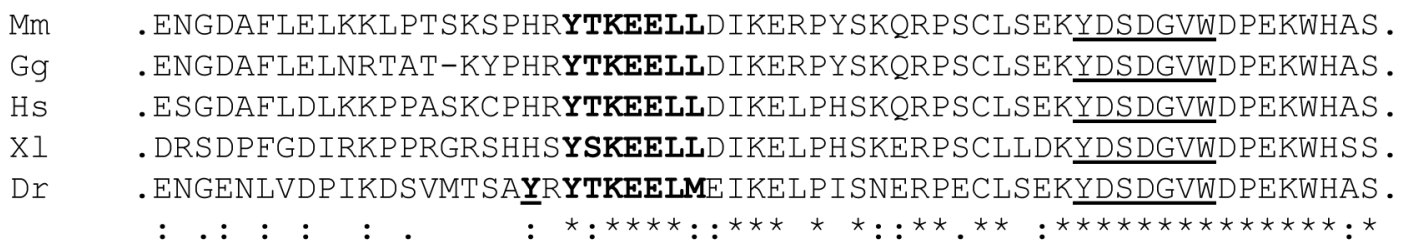

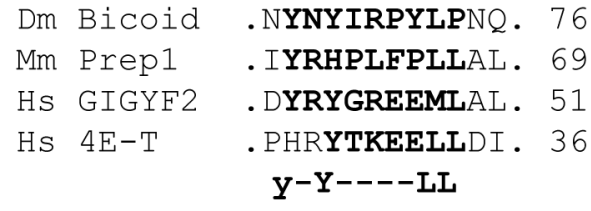

B

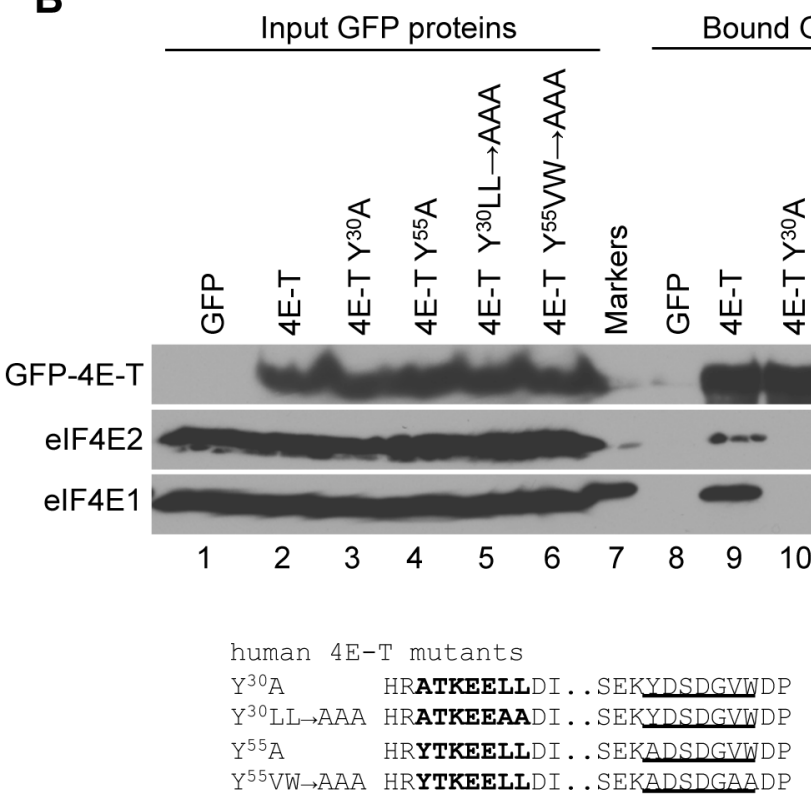

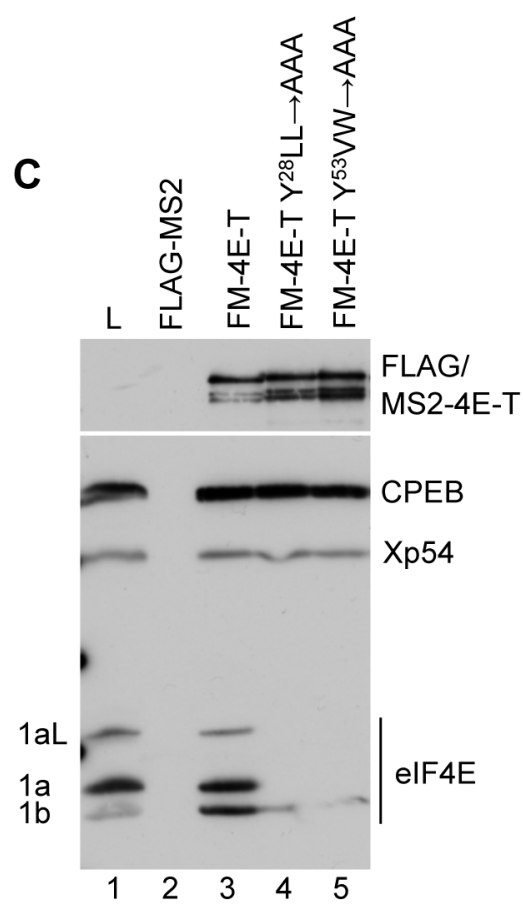

Xenopus $4 \mathrm{E}-\mathrm{T}$ mutants

$Y^{28} \mathrm{LL} \rightarrow$ AAA HSASKEEAADI. . LDKYDSDGVWDP

$Y^{53} \mathrm{LL} \rightarrow$ AAA HSYSKEELLDI . LDKADSDGAADP

Figure 3. The elF4E-binding site in 4E-T. A. Top. The sequences of the elF4E2-binding site in Dm Bicoid [17], Mm Prep1 [18], Hs GIGYF2 [19] and Hs 4E-T ( [20]. Bottom. Alignments of five indicated vertebrate 4E-T sequences using ClustalW2. In bold are indicated the elF4E-binding site residues, note the upstream tyrosine in $\mathrm{Dr} 4 \mathrm{ET}$, bold and underlined. Underlined are the residues of a potential conserved second elF4E-binding site. B. HEK293 cells were transfected with wild type or mutant GFP-4E-T as indicated and lysates were analysed by GFP-Trap and western blotting with elF4E1, elF4E2 and 4E-T antibodies. C. mRNAs encoding FLAG-MS2 and FLAG-MS2-X4E-T proteins were injected into Xenopus oocytes. After 16 hours, lysates were prepared and immunoprecipitated with FLAG antibodies, and the FLAG peptide eluates were analysed by western blotting with indicated antibodies. L lane indicates uninjected oocyte lysate. The mutations in human and Xenopus 4E-T sequences are indicated in B and C.

doi: 10.1371/journal.pone.0072761.g003

sequences is beyond the scope of this study, and clearly warrants further investigation, ideally at the structural level. We note also that the previously described downstream elF4Einteracting sequences in human $4 \mathrm{E}-\mathrm{BP}$ and elF4G proteins [42,43], located approx. 25 away from the consensus sequence, are not conserved in sequence, and are not present in $4 \mathrm{E}-\mathrm{T}$. Moreover, the downstream sequences may not necessarily interact directly with elF4E, but could enhance the ability of the canonical consensus site to form a stable $\alpha$-helix [45]. Indeed, secondary structure predictions for human or Xenopus 4E-T (using Jpred3 server: http:// www.compbio.dundee.ac.uk/www-jpred/) suggests that only the canonical binding site $Y(T / S)$ KEELL has the potential to form an a-helix, not YDSDGVW, though this does not exclude it 
A

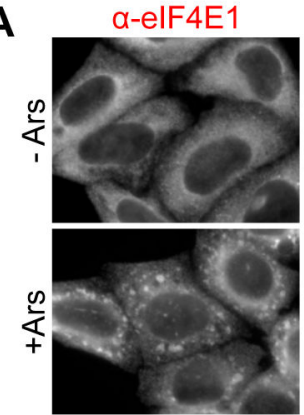

B
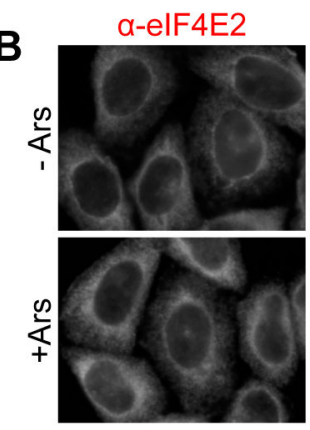

C

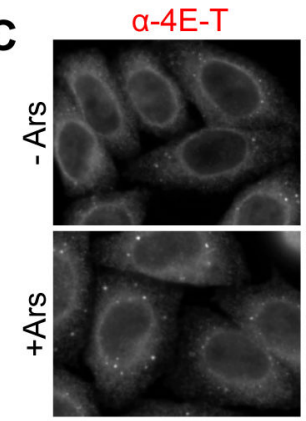

a-p54/rck

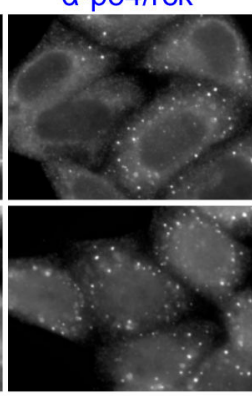

a-p54/rck
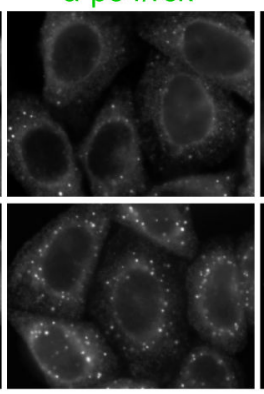

a-p54/rck

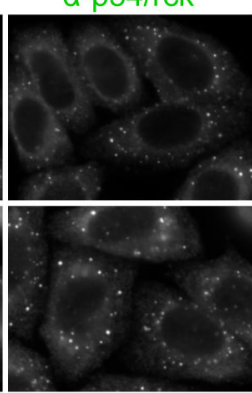

a-TIAR

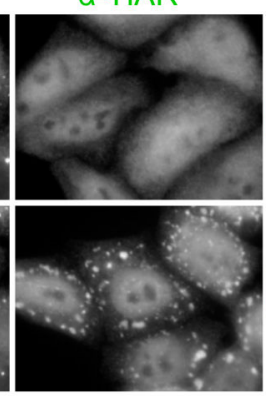

$\alpha-G 3 B P$
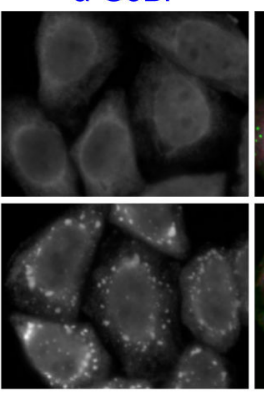

$\alpha-G 3 B P$

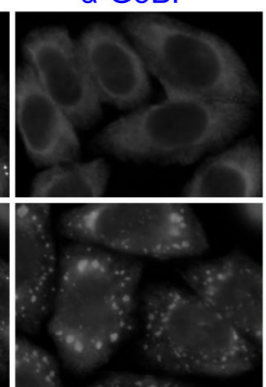

Merge

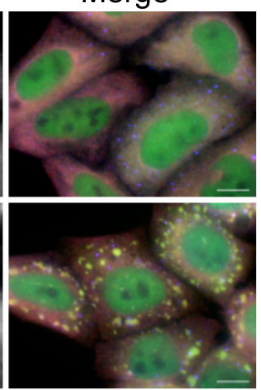

Merge

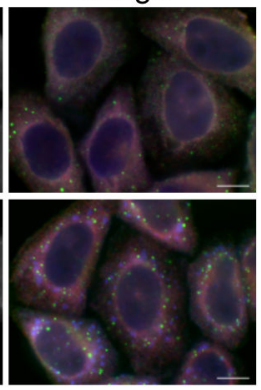

Merge

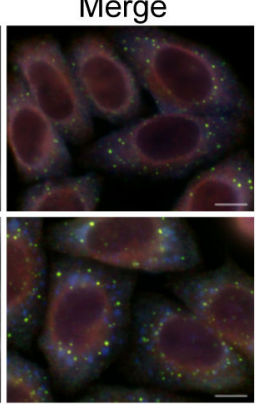

Figure 4. eIF4E1 and eIF4E2 distribution in arsenite-treated cells. Control HeLa cells (- Ars) and cells treated with arsenite (+ Ars) to induce stress granules were immunostained with elF4E1 (A), elF4E2 (B) and 4E-T (C) antibodies, and counter-stained with antibodies against p54/rck (P-body marker), and TIAR or G3BP (stress granule markers) as indicated. Scale bar, $10 \mu \mathrm{m}$.

doi: 10.1371/journal.pone.0072761.g004

from directly binding elF4E. Interestingly, the $D$. melanogaster protein Cup, related to human $4 \mathrm{E}-\mathrm{T}$, has two nearby elF4Ebinding sites, the high-affinity one which conforms to the consensus, being $\mathrm{Y}^{342} \mathrm{TRSRLM}$, with a second lower affinity and non-consensus one, ELEGRLR, some 30 residues downstream [34]. The second site binds laterally and perpendicularly in $\alpha$-helix form to the elF4E $\beta$-sheet [46], and plays a role in the stabilisation of associated mRNA [47].

\section{Unlike eIF4E1, elF4E2 does not re-localise to stress granules in arsenite-treated cells}

In addition to its native localisation in P-bodies, elF4E1 is found in stress granules in mammalian cells treated briefly with arsenite, resulting in oxidative stress [48]. Stress granules are large cytoplasmic granules, considerably larger than P-bodies, which contain stalled translation initiation complexes including elF4E, elF4A, elF4G and PABP, non-translating mRNA and
RNA-binding proteins such as G3BP and TIAR $[36,48,49]$. Like P-bodies, stress granules are dynamic complexes whose assembly is dependent on the pool of nontranslating mRNAs, and indeed the two types of mRNP granules are frequently found juxtaposed or overlapping [49,50]. Arsenite-treated HeLa cells contain typical TIAR and G3BP-containing stress granules, to which elF4E1 co-localises (Figure 4A), as shown by immunostaining. Interestingly, endogenous p54/rck remains in P-bodies adjacent to stress granules in these cells, as observed previously, though RFP-p54/rck can relocate to stress granules from the the diffuse cytoplasmic pool $[48,50]$. In contrast to elF4E1, elF4E2 remains homogenously distributed in the cytoplasm in arsenite-treated cells (Figure 4B), and 4E-T remains partly cytoplasmic and partly enriched in $\mathrm{P}$-bodies, as in untreated cells (Figure 4C). In other words, localisation of elF4E2 and 4E-T is insensitive to arsenite, unlike elF4E1, implying distinct functions to translation initiation. 
A
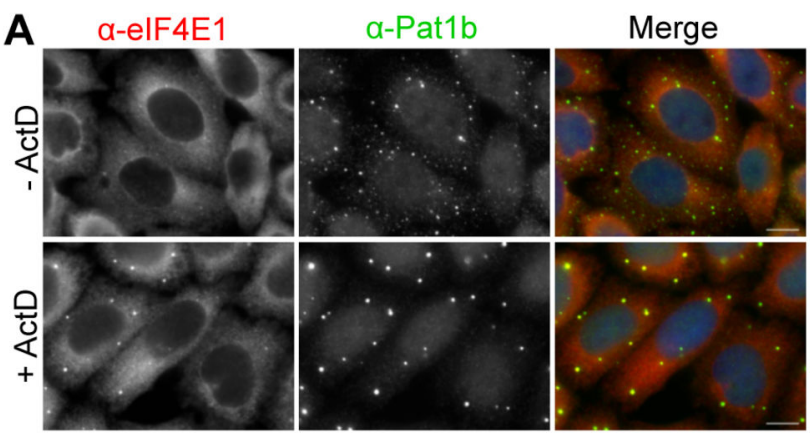

B
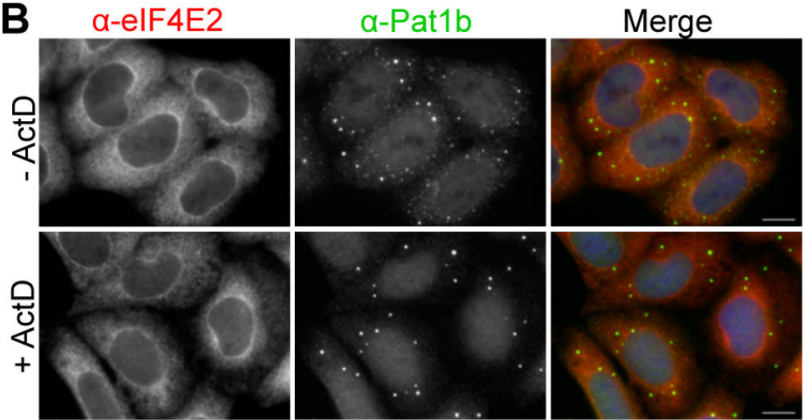

Figure 5. elF4E1 and eIF4E2 distribution in Actinomycin Dtreated cells. Control HeLa cells (- ActD) and cells treated with Actinomycin D (+ ActD) to inhibit RNA synthesis were immunostained with elF4E1 (A) and elF4E2 (B) antibodies, and counter-stained with Pat $1 \mathrm{~b}$ antibodies. Note that the apparent nuclear staining in the case of Pat $1 \mathrm{~b}$ antibody was previously shown to be insensitive to Pat1b siRNA [49]. Cells were also stained with DAPI. Scale bar, $10 \mu \mathrm{m}$.

doi: 10.1371/journal.pone.0072761.g005

\section{Inhibition of RNA transcription does not impact on eIF4E2 distribution, but enhances eIF4E1 localisation to P-bodies}

We recently showed that in HeLa cells treated with Actinomycin D for 5 hours to inhibit new RNA synthesis, the Pbody factors Pat1b, p54/rck and 4E-T were localised in fewer but bigger P-bodies than in untreated HeLa cells [51]. Particularly striking was the loss of small P-body foci upon treatment, suggesting that in the absence of new transcripts, smaller foci aggregate into larger ones. Moreover, P-bodies in Trypanosoma brucei also enlarge upon Actinomycin D treatment [52]. The cause of this increase is not clear but may be due to the reduced levels of newly synthesised mRNAs resulting in an inhibition of protein synthesis and thus an increase in P-bodies. Similarly, using Pat1b immunostaining as a control, we note that elF4E1 redistributes to P-bodies in ActD-treated HeLa cells, even in the absence of ectopic 4E-T (Figure 5A). In contrast, elF4E2 localisation in the cell is unaffected by this treatment (Figure 5B), additionally highlighting the differences between elF4E1 and elF4E2.

\section{eIF4E2 is a 4E-T-independent nucleocytoplasmic shuttling protein}

Previously, 4E-T was shown to transport elF4E1 into nuclei in cells treated with Leptomycin $B(L M B)$, which inhibits the Crm1 receptor [53], demonstrated with tagged proteins [20]. Indeed, these studies defined $4 \mathrm{E}-\mathrm{T}$ as an elF(4E-T) ransport protein. Here we demonstrate that while 4E-T (both cellular and ectopic) is nuclear in treated cells attesting to the LMB addition, elF4E1 is unresponsive to LMB in untransfected HeLa cells, and only becomes sequestered within nuclei in the presence of both GFP-4E-T and LMB (Figure $6 \mathrm{~A}$ and $\mathrm{B}$ ). $4 \mathrm{E}-\mathrm{T}$ is a nucleocytoplasmic shuttling protein, which does not require elF4E-binding to translocate to nuclei in LMB-treated cells ( [20,51], Figure S3), whereas elF4E1 requires additional 4E-T protein to visibly accumulate in nuclei in these conditions (Figure 6). This observation presumably reflects the relatively low levels of 4E-T to elF4E1 in HeLa cells (Figure 1).

In contrast, elF4E2 becomes partially nuclear in LMB-treated cells, in the absence of ectopic 4E-T, and overexpression of 4E-T does not enhance this nuclear accumulation (Figure 6C and D). To confirm this finding, 4E-T was depleted from cells using RNAi, which were subsequently treated with $L M B$ and immunostained for elF4E1, elF4E2 and 4E-T. 4E-T siRNA was shown to be effective in depleting cellular 4E-T, unlike the control $\beta$-globin siRNA (lacking a target in HeLa cells). Nevertheless, elF4E2 continues to accumulate in nuclei in LMB-treated 4E-T depleted cells, and as predicted from above, elF4E1 remains cytoplasmic (Figure 7 and Figure S4. Thus, $4 \mathrm{E}-\mathrm{T}$ is a transporter for elF4E1 only, and not for elF4E2, though 4E-T binds both proteins, and ectopic 4E-T relocalises elF4E2 to P-bodies (Figures 2 and 3; Figures S1 and S2). Previously we reported that in approx. $33 \%$ of transfected and LMB-treated cells GFP-4E-T localises in numerous foci, overlapping or close to PML bodies [49]. Here we show that the $\mathrm{Y}^{30} \mathrm{~A}$ mutation, which in such cells would only prevent elF4E1 import and not that of elF4E2, strikingly enhances the number and brightness of such GFP-4E-T foci, though the reasons for this are not known (Figure S3).

How elF4E2 enters and exits nuclei remains to be investigated, whether on its own or with a shuttling partner protein. We noted that mammalian elF4E2 proteins possess short $\mathrm{N}$ - and $\mathrm{C}$-terminal extensions relative to elF4E1 proteins, and that its $\mathrm{C}$-terminal region (in human protein) contains five conserved leucines, possibly related to the nuclear export signals (NES) in Crm1-dependent shuttling proteins. Most NES sequences conform to the consensus $\phi-(x)_{2-3}-\phi-(x)_{2-3}-\phi-x-\phi$, where $x$ is an amino acid that is preferentially charged, small or polar, and $\phi$ is hydrophobic [54]. However the spacing of the leucines in the elF4E2 C-terminal portion does not follow the consensus, and they are not conserved in vertebrates (Figure $8 \mathrm{~A}$ and B). More importantly, truncation of HA-tagged elF4E2 at amino acid 222 did not lead to elF4E2 accumulation in nuclei in the absence of LMB (Figure $8 \mathrm{C}$ ), demonstrating that they do not act as an NES. elF4E1 localisation can also be dictated by 4E-BPs [55], and this may be the case for elF4E2 as well. Irrespective of the shuttling mechanism, it is interesting to note yet another difference between elF4E1 and elF4E2, and to 
A

a-elF4E1

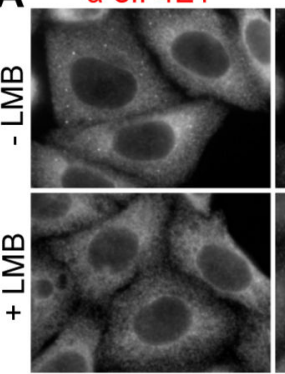

B

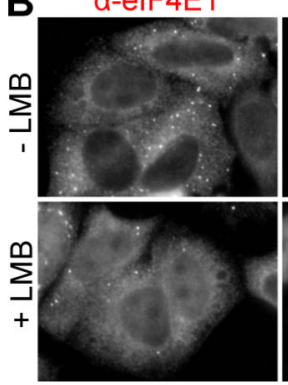

C

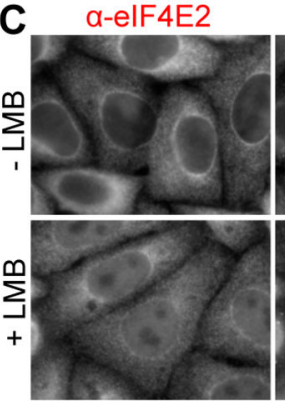

D
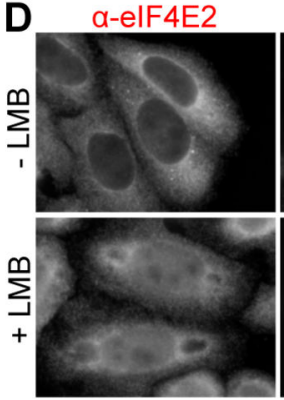

Figure 6. elF4E2 is a nucleocytoplasmic shuttling protein. Hela cells were treated with Leptomycin B for $5 \mathrm{hrs}(+$ LMB) or with methanol as control (- LMB), without (A and C) and with ectopic GFP-4E-T (B and D), and immunostained with elF4E1 (A and B), elF4E2 (C and D) and 4E-T antibodies, while GFP-4E-T fluorescence was detected directly in transfected cells. Scale bar, $10 \mu \mathrm{m}$.

doi: 10.1371/journal.pone. 0072761. g006

speculate on their nuclear functions, perhaps in specific mRNA export [56].
No siRNA

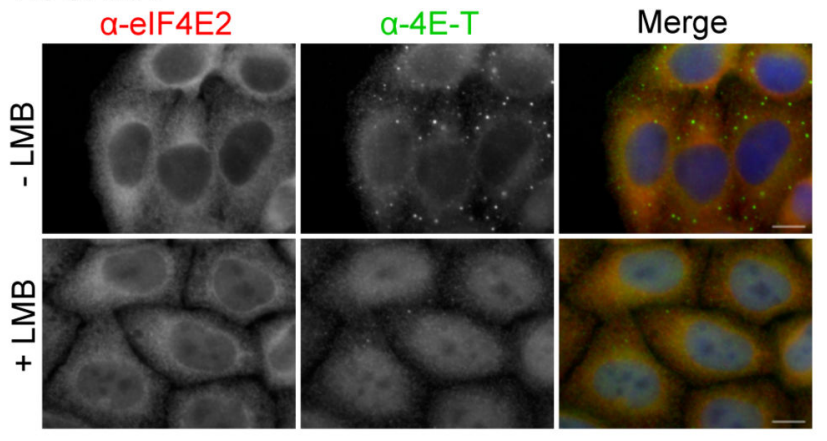

SIRNA 4E-T

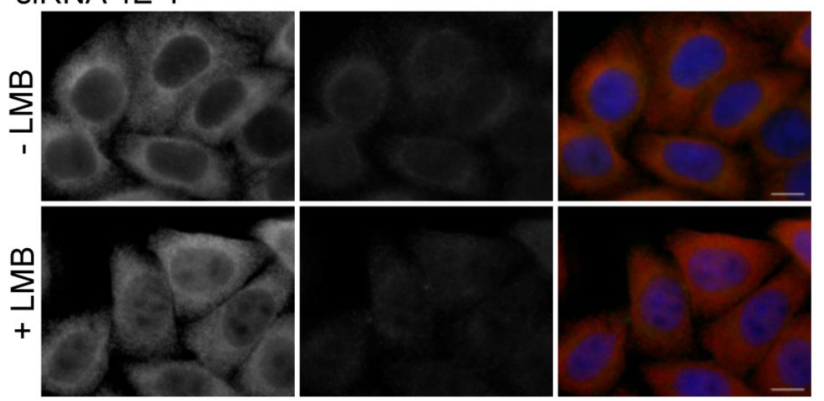

siRNA $\beta$-globin

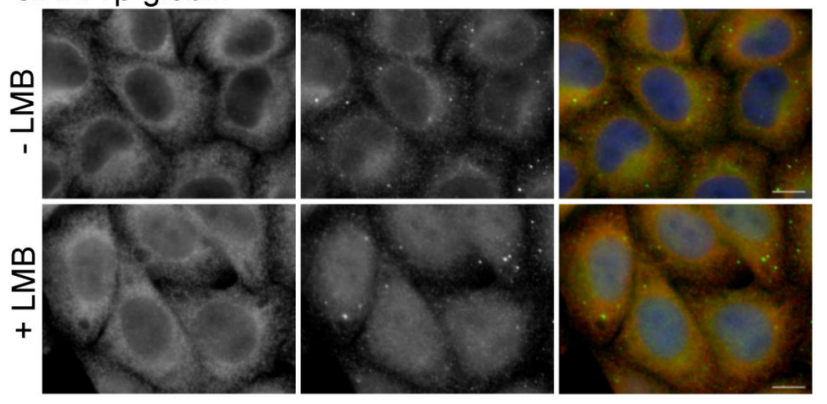

Figure 7. elF4E2 shuttling in the presence of LMB is 4E-T independent. Untransfected Hela cells (no siRNA), or cells transfected with 4E-T siRNA or control $\beta$-globin siRNA were treated with $\mathrm{LMB}$ and immunostained with elF4E2 and 4E-T antibodies as indicated. Cells were also stained with DAPI. Scale bar, $10 \mu \mathrm{m}$.

doi: 10.1371/journal.pone.0072761.g007

\section{Conclusions and Implications}

We examined the expression levels, 4E-T binding and localisation of elF4E2, a close homologue of elF4E1, but which binds the cap and elF4G weakly, and which appears to function rather as a regulator of translation. We observe that levels of elF4E1 exceed those of elF4E2 some $5-10 x$ in mammalian cells, and that both proteins interact with the low abundance $4 \mathrm{E}-\mathrm{T}$ protein via its $\mathrm{N}$-terminal $\mathrm{YX}{ }_{4} \mathrm{~L} \phi$ consensus elF4E-binding sequence also present in elF4G and 4E-BPs. Our evidence for 4E-T:elF4E2 binding was obtained in the $\mathrm{Y} 2 \mathrm{H}$ system, in HeLa cells with ectopic 4E-T recruiting elF4E2 to Pbodies, and in pull-down assays with GFP-4E-T. Examining the sequences surrounding $\mathrm{YX}{ }_{4} \mathrm{~L} \phi$ suggested that downstream 
A

HS4E2 MNNKFDALKDDDSGDHDQNEENSTQKDGEKEKTERDKNQSSSKRKAVVPGPAEHPLQYNYTFWY 64

HS4E1 ----------MATVEPETTPTPNPPTTEEEKTESNQEVANPEHYIK----HPLQNRWALWF 47

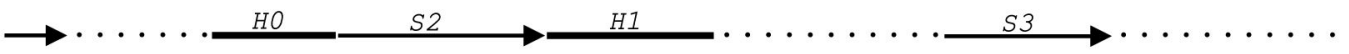

HS4E2 SRRTPGRPTSSQSYEQNIKOIGTFASVEOFWRFYSHMVRPGDLTGHSDFHLFKEGIKPMWEDDA 128

HS4E1 FKND-----KSKTWQANLRLISKFDTVEDFWALYNHIQLSSNLMPGCDYSLFKDGIEPMWEDEK 106

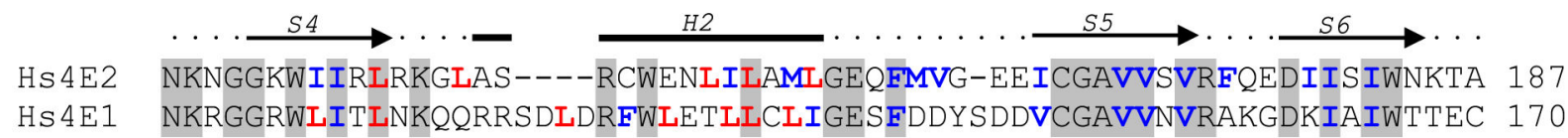

$\ldots \underset{\mathrm{H} 3}{\mathrm{~S}} \underset{\mathrm{H}}{\mathrm{H}} \mathrm{H} \ldots$

HS4E2 SDQATTARIRDTLRRVLNLP PNTIMEYKTHTDSIKMPGRLGPQRLLFQNLWKPRLNVP 245

HS 4E1 ENREAVTHIGRVYKERLGLPPKIVIGYQSHADTATKSGSTTKNRFVV----------- 217

B

Xt4E2 RRVLNLPPNTVMEYKTHTDSIKDKTSERNTKIAL----------- 234

X14E2 RRVLNLPPNTVMEYKTHTDSIKDKTSFRNTKIAL----------- 235

Mm4E2 RRVLNLPPNTIMEYKTHTDSIKMPGRLGPQRLLFQNLWKPRLNVP 245

Rn4E2 RRVLNLPPNTIMEYKTHTDSIKMPGRLGPQRLLFQNLWKPRLNVP 245

Bt4E2 RRVLNLPPNTIMEYKTHTDSIKMPGRLGSQRLLFQNLWKPRLNVP 245

Cf4E2 RRVLNLPPNTIMEYKTHTDSIKMPGRLGPQRLLFQNLWKPRLNVP 245

HS4E2 RRVLNLPPNTIMEYKTHTDSIKMPGRLGPQRLLEONLWKPRLNVP 245

Gg4E2 RRVLNLPPNTIMEYKTHTDSIKAWEEFHGLVNSSGR--------- 236

Dr4E2 RRVLNLPPNTIMEYKTHTDSIKAWEDFHGLVNASGGR-------- 236

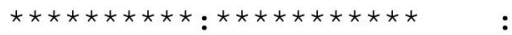

C

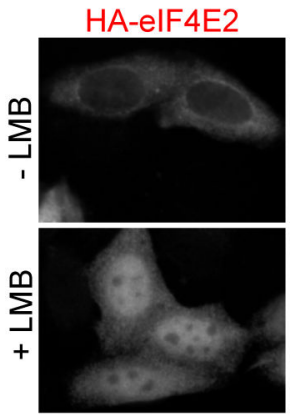

$a-4 E-T$

Merge
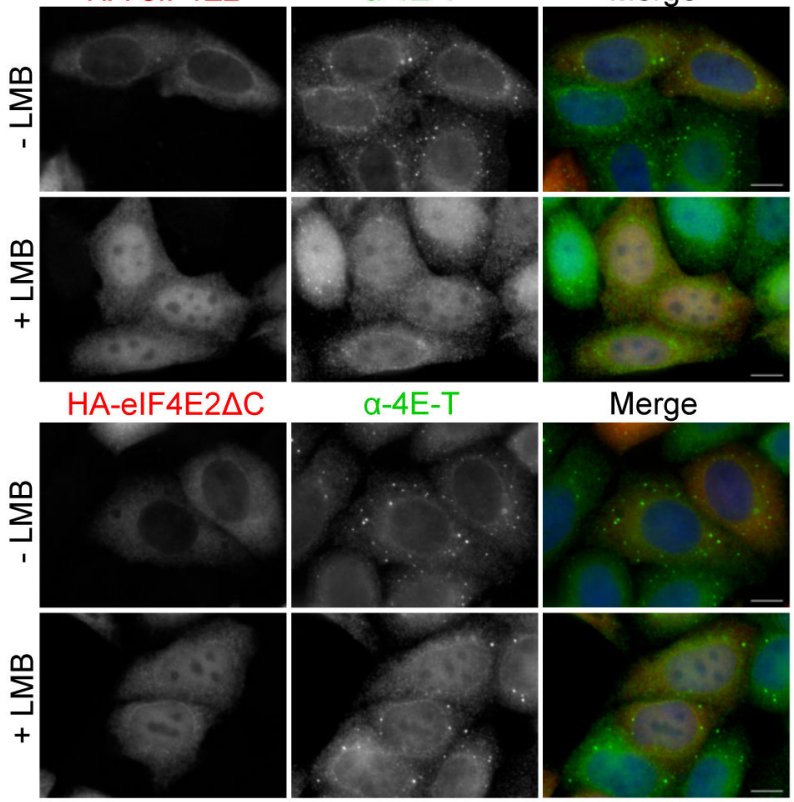

$a-4 E-T$

Merge

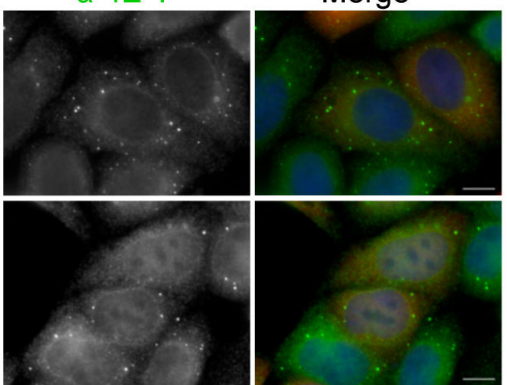

Figure 8. The leucine-rich C-terminus of elF4E2 does not act as a NES. A. Sequence alignment of human elF4E1 and elF4E2 performed with ClustalW2. Secondary structural elements of $\alpha$-helices $(\mathrm{H} 0-\mathrm{H} 4)$ and $\beta$-strands (S1-S7) were shown above the alignment according to the crystal structure of human elF4E2 in complex with $\mathrm{m}^{7}$ GTP (PDB id: 2JGB) [15]. Identities are shaded in grey. With blue and red are marked hydrophobic residues that typically form the NES. The leucine-rich C-terminus of elF4E2 is underlined in red. B. ClustalW alignment of the C-terminal regions of indicated elF4E2 proteins. C. HeLa cells transfected with HAelF4E2 full-length protein or HA-elF4E2 $\Delta C$ (truncated at residue 222) were treated with LMB or methanol (-) for 5 hrs and immunostained with HA and 4E-T antibodies as indicated. Cells were also stained with DAPI. Scale bar, $10 \mu \mathrm{m}$.

doi: 10.1371/journal.pone.0072761.g008 
sequences, possibly involving a look-alike second motif $\mathrm{YX}$ ${ }_{4} \mathrm{VW}$, were also involved in elF4E1 and elF4E2 binding, adding to our understanding of extended sequences that influence elF4E interactions with elF4G and 4E-BP proteins.

To our knowledge this is the first study reporting cellular elF4E2 distribution. In contrast to elF4E1, elF4E2 was unresponsive to both arsenite and Actinomycin $D$ treatment in terms of its localisation, and was observed to shuttle with LMB in the absence of $4 \mathrm{E}-\mathrm{T}$. Altogether we conclude that these two proteins, while clearly related at the sequence level, are likely to participate in distinct cellular processes. It is intriguing to note that RNAi-mediated depletion of elF4E2 in U87MG glioblastoma cells in normal conditions [57] has no significant effect on total protein synthesis, while in HeLa cells, an activation of approx. $30 \%$ in translation rates was reported [19], indicating a general negative role in translation. On the other hand, depletion of elF4E1, counterintuitively not apparently affecting global protein synthesis very much, leads to the degradation of hypophosphorylated 4E-BP, thus allowing the remaining low elF4E protein levels following RNAi-silencing to continue supporting translation initiation [58]. Since both elF4E proteins have been captured in global screens of RNA-binding proteins in UV cross-linked mammalian cells, as has 4E-T $[59,60]$, it will be of interest in future investigations to assess the relative binding of elF4E proteins and 4E-T to mRNA. It will also be of interest to examine to what extent their relative levels and/or activities change in different conditions, during the cell cycle or in response to signalling, for example. It is already clear that elF4E and 4E-T are subject to phosphorylation $[1,41]$, which may affect their interactions with mRNA or RNAbinding proteins, and elF4E2 can be modified by ISG15 ubiquitylation shown to significantly enhance its cap structurebinding $[61,62]$. And lastly, since elF4G dramatically enhances elF4E interaction with the mRNA 5'-cap [63], perhaps Bicoid, GIGYF2 or 4E-T may similarly regulate elF4E2 cap-binding. Indeed, it is no doubt noteworthy that elF4E2 (and elF4E1b), negative regulators of translation and components of RNAbinding complexes (see Introduction), bind the cap less efficiently than eIF4E $[16,27]$, allowing them on the one hand to interact with the cap by virtue of being tethered to particular mRNAs, and to be released from the cap on the other hand in response to cues disassembling the complex, without impeding general protein synthesis, and with the potential to be regulated by binding proteins.

\section{Acknowledgements}

We thank Nahum Sonenberg and Reinhard Luhrmann for plasmids, and Dominique Weil for discussions. Current and former members of the Darzynkiewicz and Standart labs, in particular Joanna Zuberek, Aline Marnef, Joe Piechura and Emily Hardy are gratefully acknowledged for their contributions in the early stages of the study. We also thank Mark Field and colleagues (Department of Pathology, University of Cambridge) for their help with the $\mathrm{Y} 2 \mathrm{H}$ system.

\section{Supporting Information}

Figure S1. elF4E2 interacts with 4E-T. A. Interaction shown in yeast two hybrid assay. Growth of indicated yeast bait and prey vectors in medium (SD/-Leu/-Trp) and high stringency (SD/-Ade/-His/-Leu/-Trp) plates. B. Interaction shown in pulldown assay in HeLa cell lysates overexpressing HA-elF4E2, immunoprecipitated with elF4E2 antibodies. Lanes: 0.5, 1, $2 \mu \mathrm{g}$ a-elF4E2 - resin incubated with given amount of $\alpha$-elF4E2, L HeLa cells lysate, $\mathrm{C}-$ control resin without $\alpha$-elF4E2.

(TIF)

Figure S2. Differential effects of $Y^{55} \mathrm{~A}$ mutation in GFP-4E$T$ on P-body recruitment of elF4E1 and elF4E2. Cellular elF4E1 and elF4E2 distribution in HeLa cells was assessed by indirect immunofluorescence in the presence of wild-type GFP-4E-T, and its $\mathrm{Y}^{30} \mathrm{~A}$ and $\mathrm{Y}^{55} \mathrm{~A}$ mutant versions. Red boxes indicate elF4E1 P-body staining in cells transfected with GFP-4E-T-Y55 A. Scale bar, $10 \mu \mathrm{m}$.

Figure S3. The $\mathrm{Y}^{30} \mathrm{~A}$ mutation in GFP-4E-T enhances its localisation to nuclear foci in LMB-treated cells. Cellular distribution of elF4E1 in HeLa cells transfected with wild-type GFP-4E-T, and its $\mathrm{Y}^{30} \mathrm{~A}$ mutant version, and treated with $\mathrm{LMB}$ $(+)$ or methanol vehicle (-). Cells were also stained with DAPI. Scale bar, $10 \mu \mathrm{m}$.

(TIF)

Figure S4. 4E-T depletion does not affect elF4E1 localisation in the presence of LMB. Untransfected Hela cells (no siRNA), or cells transfected with 4E-T siRNA or control $\beta$-globin siRNA were treated with LMB and immunostained with elF4E1 and 4E-T antibodies. Cells were also stained with DAPI. Scale bar, $10 \mu \mathrm{m}$.

(TIF)

Table S1. Oligonucleotide sequences used for cloning and mutagenesis.

(DOC)

\section{Author Contributions}

Conceived and designed the experiments: DK AK HB NM NS. Performed the experiments: DK AK HB NM. Analyzed the data: DK AK HB NM ED NS. Wrote the manuscript: DK ED NS. Obtained funding for the work: ED NS. 


\section{References}

1. Furic L, Rong L, Larsson O, Koumakpayi IH, Yoshida K et al. (2010) elF4E phosphorylation promotes tumorigenesis and is associated with prostate cancer progression. Proc Natl Acad Sci USA 107: 14134-14139. doi:10.1073/pnas.1005320107. PubMed: 20679199.

2. Ruggero D, Montanaro L, Ma L, Xu W, Londei P et al. (2004) The translation factor elF-4E promotes tumor formation and cooperates with c-Myc in lymphomagenesis. Nat Med 10: 484-486. doi:10.1038/ nm1042. PubMed: 15098029.

3. Santini E, Huynh TN, MacAskill AF, Carter AG, Pierre P et al. (2013) Exaggerated translation causes synaptic and behavioural aberrations associated with autism. Nature 493: 371-377. PubMed: 23172145.

4. Gkogkas CG, Khoutorsky A, Ran I, Rampakakis E, Nevarko T et al. (2012) Autism-related deficits via dysregulated elF4E-dependent translational control. Nature (. (2013)) PubMed: 23172145.

5. Jackson RJ, Hellen CU, Pestova TV (2010) The mechanism of eukaryotic translation initiation and principles of its regulation. Nat Rev Mol Cell Biol 11: 113-127. doi:10.1038/nrm2838. PubMed: 20094052.

6. Aitken CE, Lorsch JR (2012) A mechanistic overview of translation initiation in eukaryotes. Nat Struct Mol Biol 19: 568-576. doi:10.1038/ nsmb.2303. PubMed: 22664984.

7. Kong J, Lasko P (2012) Translational control in cellular and developmental processes. Nat Rev Genet 13: 383-394. doi:10.1038/ nrg3184. PubMed: 22568971.

8. Hernández G, Altmann M, Sierra JM, Urlaub H, del Corral RD et al. (2005) Functional analysis of seven genes encoding eight translation initiation factor 4E (elF4E) isoforms in Drosophila. Mech Dev 122: 529-543. doi:10.1016/j.mod.2004.11.011. PubMed: 15804566.

9. Tettweiler G, Kowanda M, Lasko P, Sonenberg N, Hernández G (2012) The Distribution of elF4E-Family Members across Insecta. PubMed: 22745595.

10. Keiper BD, Lamphear BJ, Deshpande AM, ankowska-Anyszka M, Aamodt EJ et al. (2000) Functional characterization of five elF4E isoforms in Caenorhabditis elegans. J Biol Chem 275: 10590-10596. doi:10.1074/jbc.275.14.10590. PubMed: 10744754

11. Rhoads RE (2009) elF4E: new family members, new binding partners, new roles. J Biol Chem 284: 16711-16715. doi:10.1074/ jbc.R900002200. PubMed: 19237539.

12. Joshi B, Cameron A, Jagus $R$ (2004) Characterization of mammalian elF4E-family members. Eur J Biochem 271: 2189-2203. doi:10.1111/j. 1432-1033.2004.04149.x. PubMed: 15153109.

13. Joshi B, Lee K, Maeder DL, Jagus R (2005) Phylogenetic analysis of elF4E-family members. BMC Evol Biol 5: 48 . doi: 10.1186/1471-2148-5-48. PubMed: 16191198.

14. Rom E, Kim HC, Gingras AC, [!(surname)!], Favre D et al. (1998) Cloning and characterization of 4EHP, a novel mammalian elF4Erelated cap-binding protein. J Biol Chem 273: 13104-13109. doi: 10.1074/jbc.273.21.13104. PubMed: 9582349.

15. Rosettani P, Knapp S, Vismara MG, Rusconi L, Cameron AD (2007) Structures of the Human elF4E Homologous Protein, h4EHP, in its m(7)GTP-bound and Unliganded Forms. J Mol Biol 368: 691-705. doi: 10.1016/j.jmb.2007.02.019. PubMed: 17368478 .

16. Zuberek J, Kubacka D, Jablonowska A, Jemielity J, Stepinski J et al. (2007) Weak binding affinity of human 4EHP for mRNA cap analogs. RNA 13: 691-697. doi:10.1261/rna.453107. PubMed: 17369309.

17. Cho PF, Poulin F, Cho-Park YA, Cho-Park IB, Chicoine JD et al. (2005) A new paradigm for translational control: inhibition via 5'-3' mRNA tethering by Bicoid and the elF4E cognate 4EHP. Cell 121: 411-423 doi:10.1016/j.cell.2005.02.024. PubMed: 15882623.

18. Villaescusa JC, Buratti C, Penkov D, Mathiasen L, Planagumà J et al. (2009) Cytoplasmic Prep1 interacts with 4EHP inhibiting Hoxb4 translation. PLOS ONE 4: e5213. doi:10.1371/journal.pone.0005213. PubMed: 19365557

19. Morita M, Ler LW, Fabian MR, Siddiqui N, Mullin M et al. (2012) A Novel 4EHP-GIGYF2 Translational Repressor Complex Is Essential for Mammalian Development. Mol Cell Biol 32: 3585-3593.

20. Dostie J, Ferraiuolo M, Pause A, Adam SA, Sonenberg N (2000) A novel shuttling protein, 4E-T, mediates the nuclear import of the mRNA 5' cap-binding protein, elF4E. EMBO J 19: 3142-3156. doi:10.1093/ emboj/19.12.3142. PubMed: 10856257.

21. Ferraiuolo MA, Basak S, Dostie J, Murray EL, Schoenberg DR et al. (2005) A role for the elF4E-binding protein in P-body formation and mRNA decay. J Cell Biol 170: 913-924. doi:10.1083/jcb.200504039. PubMed: 16157702.

22. Andrei MA, Ingelfinger D, Heintzmann R, Achsel T, Rivera-Pomar R et al. (2005) A role for elF4E and elF4E-transporter in targeting mRNPs to mammalian processing bodies. RNA 11: 717-727. doi:10.1261/rna. 2340405. PubMed: 15840819.
23. Lee HC, Cho $\mathrm{H}$, Kim YK (2008) Ectopic expression of elF4Etransporter triggers the movement of elF4E into P-bodies, inhibiting steady-state translation but not the pioneer round of translation. Biochem Biophys Res Commun 369: 1160-1165. doi:10.1016/j.bbrc. 2008.03.017. PubMed: 18343217

24. Eulalio A, Behm-Ansmant I, Izaurralde $E$ (2007) P bodies: at the crossroads of post-transcriptional pathways. Nat Rev Mol Cell Biol 8: 9-22. doi:10.1038/nrg1981. PubMed: 17183357.

25. Parker R, Sheth $U$ (2007) $P$ bodies and the control of mRNA translation and degradation. Mol Cell 25: 635-646. doi:10.1016/j.molcel. 2007.02.011. PubMed: 17349952.

26. Kulkarni M, Ozgur S, Stoecklin G (2010) On track with P-bodies. Biochem Soc Trans 38: 242-251. doi:10.1042/BST0380242. PubMed: 20074068.

27. Minshall N, Reiter M-H, Weil D, Standart N (2007) CPEB interacts with an ovary-specific elF4E and 4E-T in early Xenopus oocytes. J Biol Chem 282: 37389-37401. doi:10.1074/jbc.M704629200. PubMed: 17942399.

28. Minshall N, Kress M, Weil D, Standart N (2009) Role of p54 RNA helicase activity and its C-terminal domain in translational repression, P-body localization and assembly. Mol Biol Cell 20: 2464-2472. doi: 10.1091/mbc.E09-01-0035. PubMed: 19297524

29. Fernández-Miranda G, Méndez R (2012) The CPEB-family of proteins, translational control in senescence and cancer. Ageing Res Rev 11: 460-472. doi:10.1016/j.arr.2012.03.004. PubMed: 22542725.

30. Weill L, Belloc E, Bava FA, Méndez R (2012) Translational control by changes in poly $(A)$ tail length: recycling mRNAs. Nat Struct Mol Biol 19: 577-585. doi:10.1038/nsmb.2311. PubMed: 22664985.

31. Evsikov AV, Marín de Evsikova C (2009) Evolutionary origin and phylogenetic analysis of the novel oocyte-specific eukaryotic translation initiation factor 4E in Tetrapoda. Dev Genes Evol 219: 111-118. doi: 10.1007/s00427-008-0268-2. PubMed: 19089447

32. Standart N, Minshall N (2008) Translational control in early development: CPEB, P-bodies and germinal granules. Biochem Soc Trans 36: 671-676. doi:10.1042/BST0360671. PubMed: 18631138.

33. Nakamura A, Sato K, Hanyu-Nakamura K (2004) Drosophila Cup is an elF4E binding protein that associates with Bruno and regulates oskar mRNA translation in oogenesis. Dev Cell 6: 69-78. doi:10.1016/ S1534-5807(03)00400-3. PubMed: 14723848

34. Nelson MR, Leidal AM, Smibert CA (2004) Drosophila Cup is an elF4Ebinding protein that functions in Smaug-mediated translational repression. EMBO J 23: 150-159. doi:10.1038/sj.emboj.7600026. PubMed: 14685270.

35. Marnef $A$, Maldonado M, Bugaut A, Balasubramanian S, Kress $M$ et al (2010) Distinct functions of maternal and somatic Pat1 protein paralogs. RNA 16: 2094-2107. doi:10.1261/rna.2295410. PubMed: 20826699.

36. Wilczynska A, Aigueperse C, Kress M, Dautry F, Weil D (2005) The translational regulator CPEB1 provides a link between Dcp1 bodies and stress granules. J Cell Sci 118: 981-992. doi:10.1242/jcs.01692. PubMed: 15731006

37. Beck M, Schmidt A, Malmstroem J, Claassen M, Ori A et al. (2011) The quantitative proteome of a human cell line. Mol Syst Biol 8: 549.

38. Nagaraj N, Wisniewski JR, Geiger T, Cox J, Kircher M et al. (2011) Deep proteome and transcriptome mapping of a human cancer cell line. Mol Syst Biol 8: 548.

39. Schwanhäusser B, Busse D, Li N, Dittmar G, Schuchhardt J et al (2011) Global quantification of mammalian gene expression control. Nature 473: 337-342. doi:10.1038/nature10098. PubMed: 21593866.

40. Rual JF, Venkatesan K, Hao T, Hirozane-Kishikawa T, Dricot A et al. (2005) Towards a proteome-scale map of the human protein-protein interaction network. Nature 437: 1173-1178. doi:10.1038/nature04209. PubMed: 16189514

41. Cargnello M, Tcherkezian J, Dorn JF, Huttlin EL, Maddox PS et al. (2012) 4E-T Phosphorylation by JNK Promotes Stress-dependent Pbody Assembly. Mol Cell Biol 32: 4572-4584. doi:10.1128/MCB. 00544-12. PubMed: 22966201.

42. Umenaga Y, Paku KS, In Y, Ishida T, Tomoo K (2011) Identification and function of the second elF4E-binding region in $\mathrm{N}$-terminal domain of elF4G: comparison with elF4E-binding protein. Biochem Biophys Res Commun 414: 462-467. doi:10.1016/j.bbrc.2011.09.084. PubMed: 21964297.

43. Paku KS, Umenaga Y, Usui T, Fukuyo A, Mizuno A et al. (2012) A conserved motif within the flexible $\mathrm{C}$-terminus of the translational regulator $4 \mathrm{E}-\mathrm{BP}$ is required for tight binding to the mRNA cap-binding protein elF4E. Biochem J 441: 237-245. doi:10.1042/BJ20101481. PubMed: 21913890. 
44. Trinkle-Mulcahy L, Boulon S, Lam YW, Urcia R, F-M. B, et al. (2008) Identifying specific protein interaction partners using quantitative mass spectrometry and bead proteomes. J Cell Biol 183: 223-239

45. Brown CJ, Lim JJ, Leonard T, Lim HC, Chia CS et al. (2011) Stabilizing the elF4G1 $\alpha$-helix increases its binding affinity with elF4E: implication for peptidomimetic design strategies. J Mol Biol 405: 736-753. doi: 10.1016/j.jmb.2010.10.045. PubMed: 21094167.

46. Kinkelin K, Veith K, Grünwald M, Bono F (2012) Crystal structure of a minimal elF4E-Cup complex reveals a general mechanism of elF4E regulation in translational repression. RNA 18: 1624-1634. doi:10.1261/ rna.033639.112. PubMed: 22832024.

47. Igreja C, Izaurralde E (2011) CUP promotes deadenylation and inhibits decapping of mRNA targets. Genes Dev 25: 1955-1967. doi:10.1101/ gad.17136311. PubMed: 21937713.

48. Kedersha N, Anderson $P$ (2007) Mammalian stress granules and processing bodies. Methods Enzymol 431: 61-81. doi:10.1016/ S0076-6879(07)31005-7. PubMed: 17923231.

49. Decker CJ, Parker R (2012) P-bodies and stress granules: possible roles in the control of translation and mRNA degradation. Cold Spring Harb Perspect Biol 4: a012286. doi:10.1101/cshperspect.a012286. PubMed: 22763747

50. Mollet S, Cougot N, Wilczynska A, Dautry F, Kress M et al. (2008) Translationally repressed mRNA transiently cycles through stress granules during stress. Mol Biol Cell 19: 4469-4479. doi:10.1091/ mbc.E08-05-0499. PubMed: 18632980.

51. Marnef A, Weil D, Standart N (2012) RNA-related nuclear functions of human Pat1b, the P-body mRNA decay factor. Mol Biol Cell 23: 213-224.

52. Kramer S, Marnef A, Standart N, Carrington M (2012) Inhibition of mRNA maturation in trypanosomes causes the formation of novel foci at the nuclear periphery containing cytoplasmic regulators of mRNA fate. J Cell Sci 125: 2896-2909. doi:10.1242/jcs.099275. PubMed: 22366449.

53. Stade K, Ford CS, Guthrie C, Weis K (1997) Exportin 1 (Crm1p) is an essential nuclear export factor. Cell 90: 1041-1050. doi:10.1016/ S0092-8674(00)80370-0. PubMed: 9323132.
54. Kutay U, Güttinger S (2005) Leucine-rich nuclear-export signals: born to be weak. Trends Cell Biol 15: 121-124. doi:10.1016/j.tcb. 2005.01.005. PubMed: 15752974

55. Rong L, Livingstone M, Sukarieh R, Petroulakis E, Gingras AC et al. (2008) Control of elF4E cellular localization by elF4E-binding proteins, 4E-BPs. RNA 14: 1318-1327. doi:10.1261/rna.950608. PubMed: 18515545.

56. Culjkovic-Kraljacic B, Baguet A, Volpon L, Amri A, Borden KL (2012) The Oncogene elF4E Reprograms the Nuclear Pore Complex to Promote mRNA Export and Oncogenic Transformation. Cell Rep 2: 207-215. doi:10.1016/j.celrep.2012.07.007. PubMed: 22902403.

57. Uniacke J, Holterman CE, Lachance G, Franovic A, Jacob MD et al (2012) An oxygen-regulated switch in the protein synthesis machinery. Nature 486: 126-129. PubMed: 22678294.

58. Yanagiya A, Suyama E, Adachi H, Svitkin YV, Aza-Blanc P et al. (2012) Translational homeostasis via the mRNA cap-binding protein, elF4E. Mol Cell 46: 847-858. doi:10.1016/j.molcel.2012.04.004. PubMed: 22578813.

59. Baltz AG, Munschauer M, Schwanhäusser B, Vasile A, Murakawa $Y$ et al. (2012) The mRNA-Bound Proteome and Its Global Occupancy Profile on Protein-Coding Transcripts. Mol Cell 46: 674-690. doi: 10.1016/j.molcel.2012.05.021. PubMed: 22681889.

60. Castello A, Fischer B, Eichelbaum K, Horos R, Beckmann BM et al (2012) Insights into RNA Biology from an Atlas of Mammalian mRNABinding Proteins. Cell 149: 1393-1406. doi:10.1016/j.cell.2012.04.031. PubMed: 22658674

61. Tan NG, Ardley HC, Scott GB, Rose SA, Markham AF et al. (2003) Human homologue of ariadne promotes the ubiquitylation of translation initiation factor 4E homologous protein, 4EHP. FEBS Lett 554: 501-504. doi:10.1016/S0014-5793(03)01235-3. PubMed: 14623119.

62. Okumura F, Zou W, Zhang DE (2007) ISG15 modification of the elF4E cognate 4EHP enhances cap structure-binding activity of 4EHP. Genes Dev 21: 255-260. doi:10.1101/gad.1521607. PubMed: 17289916.

63. Haghighat A, Sonenberg N (1997) elF4G dramatically enhances the binding of elF4E to the mRNA 5'-cap structure. J Biol Chem 272: 21677-21680. doi:10.1074/jbc.272.35.21677. PubMed: 9268293. 